\title{
The Society of Control and the Managed Citizen
}

In his brief but prescient essay, "Postscript on Control Societies,"1 Gilles Deleuze suggested that in control societies, as opposed to the disciplinary societies of the previous socio-historical formation brilliantly analysed by Michel Foucault, capitalism has mutated into a ubiquitous "international ecumenical organisation" with the capacity to corral into a single comprehensive system even the most disparate structures (scientific, religious, artistic, play and leisure, etc.) and kinds of being. In this new epoch, productive labour is dominated by new forms of intellectual production and service provision, which are now able to regulate every sector of social life. Consciousness, the affective and emotional components of human life, and the underlying biological bases of these components, are no longer left to "private" spheres but are instead relentlessly capitalised by this new regime of accumulation.

In this epoch, the boundary between State and Society is effectively abolished: State and Society are now a single universe of interlinked networks, in which all capital can in principle be expressed as social capital. Within this novel context, the production of social cooperation, primarily by the service and information industries, has become crucial for capitalism. Capitalism has to ensure that the forms of social cooperation are under its constant control, and this in turn requires that education, training, the work time-cycle, and so on, never really end. The business time-scale is now " $24 / 7$ " so that the Tokyo stock exchange is running when the one in New York closes, in a ceaseless cycle; training nowadays is "on the job" as opposed to being based on the traditional apprenticeship model (itself a holdover from feudalism); with internet banking and financial services one can conduct financial transactions virtually every minute of the day; and education becomes "continuing education," that is, something that continues throughout life, and is not confined to those aged 6-22. This cultural propensity, whose heart is the computer-driven system of vastly ramified communications networks, is reflected in the current regime of capitalist accumulation, where production has become metaproduction, that is, no longer focused - in the advanced economies at any rate - on the use of raw materials to produce finished goods, but rather on the sale of services (especially in the domain of finance and credit) and the generation of "know how," a kind of theoretical expertise which can be sold to less advanced countries to be turned into finished products. 
Social control is no longer left to schools and police forces, but is now a branch of marketing, as even politics has become "retail politics," in which politicians seek frantically for an image of themselves to hawk to the electorate, and public relations consultants are more important to prime ministers and presidents than trustworthy and well-trained civil servants (more will be said about this later). Recording, whether in administration or business, is no longer based on the written document kept in the appropriate box of files, but on bar-coding and other forms of electronic tagging, as well as a myriad number of data-processing instruments.

The implications of the above-mentioned developments for politics are simply momentous, and the ensuing sections will consider them in an American context, the assumption being that the American version of this mode of societal regulation is the one most expressive of the current capitalist system of accumulation. The emphasis will be on the creation of the form of political subjectivity most congruent with the structures and strategies put in place by control societies.

\section{THE NEW MODE OF SOCIETAL REGULATION}

In addition to an economic order (whose governing logic is the macroeconomic relation between investment, production, and accumulation) there is also a political order governed by another quite specific logic of power accumulation or domination, and a domestic order governed by a logic of "human resource" reproduction - this domestic order being the source of economic accumulation as well as of the political accumulation of power. ${ }^{2}$ These three orders have been decisively transformed in societies of control.

The reproduction of human resources, anodyne though this phrase may sound, involves at its core the reproduction of subjectivities and identities. Anyone inclined to doubt the necessity of this set of societal operations focused on the reproduction of subjectivities and identities need only consider how the political ascendancy of the Republican Party in the United States is due in large part to a carefully nurtured coalition between pro-business interests and networks of conservative Christian evangelicals. ${ }^{3}$ And where the constitution of the subjectivities and identities of conservative American Christian evangelicals is concerned, the convergence of a number of key factors had to be achieved before this group could contribute to this Republican Party ascendancy. These included cultural norms (especially a particular ideology of the nuclear family that would however have been starkly incomprehensible to the first Christians); a moral code with a specific conception of "values" (the anti-abortion, anti-gay rights, pro-death penalty, etc., stance of many conservative American evangelicals); a repertoire of religious doctrines (having primarily to do with what has come to be called "the gospel of success" - i.e. "with Jesus on your side you can become a millionaire, win the lottery, clinch the deal," etc.); access to the media (especially television and the Internet); as well as the ability to acquire significant streams of revenue. Hence, if Christians in the United States had been formed in terms of their subjectivity and identity in the way that European Lutherans are, or impoverished Catholics living in a Brazilian favella are, say, then the likelihood of their being professed Christians and supporters of anything like a neo-conservative agenda are slim, if not nonexistent. For any group to be formed into political agents of a distinctive kind (and here American evangelical Christians are no exception), certain "mentalities" have

12 Surin - Society of Control - Junctures, 8, Jun 2007 
to be cultivated at the expense of others, and certain ideals and conceptions of "truth" and "goodness" have to be promoted while others are not. Only when this was accomplished could an alliance between business interests and conservative Christian evangelicals be brought about on behalf of the Republican Party, and the seemingly counterintuitive alliance between Christianity and a blatantly pro-business ideology be enabled.

After all, it is not immediately obvious why individuals who profess to be Christians should be so accommodating of the Halliburtons and Enrons of this world, or be vociferous enthusiasts for an invasion of Iraq (here it is perhaps notable that both the late John Paul II and his successor Benedict XVI, neither of them renowned for their liberal proclivities, were publicly opposed to the American invasion of Iraq, while the American churches have been noticeably silent on the morality of this invasion). Only when a convergence (or "strategic coupling" in the words of Bob Jessop) between the economic mode of production and the socio-political mode of domination is realized, can a situation be brought about in which it is easy for the Enrons and Halliburtons of this world to operate with the consent, explicit or tacit, of the overwhelming majority of American citizens. ${ }^{4}$

An almost perfect concrete illustration of how this "control society" socio-economic mode of domination operates is provided by the typical campaign pitch of the three-term Republican senator Phil Gramm of Texas, who also ran for president in 1996. Gramm would often challenge his Texan electorate to choose between "pulling the wagon" (i.e. being someone who "worked hard," etc.) and "riding the wagon" (i.e. being someone who milked the welfare system, etc.). ${ }^{5}$ The ideological tilt of this challenge is not difficult to discern: most Texan voters would want to see themselves as hard-working pullers of the wagon, and not the shirkers and parasites who sponge off the hard-working souls being psychologically enticed by Gramm into identifying with, and thus voting for him (heaven forbid that Senator Gramm should appear to be anything but a wagon-puller!). The truth of the matter however is the total opposite. While the "pullers of the wagon" are those who in the main would like to see themselves as "hard-working" Texans, those who are the wagon's "passengers" are much more likely to be the hugely wealthy CEOs of Enron, Halliburton, and Worldcom (that is to say, the kind of entrepreneur who typically enjoyed Gramm's unflinching support while he was a politician), and so on, as opposed to the run-of-the-mill welfare scrounger whom Gramm invited his electorate to despise - i.e. someone who, no matter how ingenious they are in their attempts to get a free ride out of the welfare system, will only be able to bilk this system of the tiniest fraction of what a CEO like Bernie Ebbers or the late Ken Lay would have acquired as a result of the fraudulent practices of a Worldcom or Enron.

A mode of societal regulation rendering inevitable and acceptable practices such as the one which gave Phil Gramm an 18-year stint in the US Senate merits analysis. An aura of eye-winking acceptability is conferred by this mode of societal regulation on the conduct of politicians like Gramm and business executives like Enron's Ken Lay (at least until Enron's senior executives were caught with their fingers in the proverbial till), as indeed it is with regard to a whole range of business practices (the recent scandal involving the Republican lobbyist Jack Abramoff is especially revealing in this regard, though at the time of writing not all the facts of this case have been disclosed). 
The distinctive phenomenological features of this "control society," and overwhelmingly American mode of societal regulation include the following:

(i) an inveterate patriotism, involving the unchallengeable conviction that America's special place in the global order is one that it is absolutely entitled to;

(ii) a disposition to favour "business" solutions over those based on an adequately functioning civil society (or at any rate, the interests of civil society in the US are presumed by its ruling élite to be absolutely coextensive with those of its corporations);

(iii) appeals to religion, especially those invoking notions of a special providence guiding America and those who pledge their allegiance to it;

(iv) a decided preference for incarceration and execution as the "best" way to deal with social ills;

(v) the equation of wealth with supposed virtue, so that poverty comes to possess a taint of criminality or individual dereliction (given expression in the catchphrase sometimes heard on right-wing talk radio shows: “If you're so smart, and you ain't rich, what's wrong with you?");

(vi) the conviction that the United States gives much, very much, more to the rest of the world than other countries and their citizens give to it ("America, the indispensable nation," in the words of former Secretary of State Madeleine Albright);

vii) the fantasy, common to both Republican and Democratic politicians and the mass media, that everyone in America is "middle class" or belongs to a "working family" (but never the working class, which cannot be mentioned because that would be to subscribe to "class warfare"). Thus the class origins of income inequities are effaced at a single stroke, since presumably Bill and Melinda Gates and their children somehow constitute a "working family"; and the overwhelmingly African-American janitors at my university are "middle class" (like the Gates family?), even though some of them have to hold two or even three jobs to pay the rent, afford health care and a retirement plan, and provide for their children's educations, etc.;

viii) low levels of political participation, as witnessed by the fact that over half the citizens do not vote ${ }^{6}$; and

ix) related ideologically to (vii) is the culturally-sanctioned propensity to accept relatively high levels of inequality as the unavoidable consequence of being a "society of opportunity and freedom", "a culture of enterprise and competition", etc. ${ }^{7}$

This mode of societal regulation operates in tandem with its concomitant mode of economic production. Here of course the unavoidable fact is the US's abandonment of the postwar "compromise" between labor and capital, reflected in such programs as Lyndon Johnson's "Great Society," but swiftly abandoned when the implicit or explicit Keynesianism underpinning that "compromise" unraveled in the early 1970s, as the US then made a rapid transition from Keynesianism to neoliberalism in accordance with the American ruling élite's preferred way of dealing with the "stagflation" that ensued from the termination of this historic "compromise." This abandonment of the so-called Keynesian "compromise" became the core of the ensuing 
"neoliberalism," with its emphasis on the market as the unquestioned universal mechanism for dealing with every kind of problem ("market fundamentalism"), thereby encompassing the cultural and the social, as much as the financial and entrepreneurial, domains. The theoretical underpinnings of this new regime of accumulation gained widespread credence, and became a conventional wisdom all over the world; the Chile of General Pinochet, the Britain of Mrs Thatcher, the Italy of Silvio Berlusconi, the Japan of Junichiro Koizumi, the New Zealand of then Prime Minister Jim Bolger, and international organisations such as the IMF and World Bank, all endorsed this conventional wisdom.

The core of this succeeding regime of accumulation, when adequately described and analysed, soon expresses the not-so-secret result of this transition to a neoliberal strategy of accumulation. In essence, the power of labor in relation to capital had, for this neoliberal regime of accumulation, to be reduced drastically; and the power of capital, especially the burgeoning forms of financial capital, had to be expanded at the expense of those whose incomes were wage-based.

The most immediate outcome of this shift to a form of accumulation privileging forms of income not based on the wage relation was a growing inequality. In particular, with an increased percentage of managerial remuneration being dispensed in the form of stock options - creating what Gérard Duménil and Dominique Lévy call "the ownership-management interface" - managers of corporations were given a huge incentive to maximize "stockholder value" at the expense of all other business considerations, such as long-term investment in their enterprises, and so on. ${ }^{8}$ However, those workers constrained by the wage relation could not enhance their income in this way. How many stock options can a factory worker making $\$ 70,000$ a year (which is a respectable wage for "blue collar" jobs, since it is almost one-anda-half times the current median US income) hold in comparison to an executive who makes $\$ 700,000$ a year (which is not after all a huge salary for most Fortune 500 American business executives)? The differences between CEO income and the incomes of those relying on waged work is staggering: CEOs have been able to reward themselves with big payments, typically in the form of stock options and other kinds of "partnership income," while in real terms US wages have declined. The result is a new rapprochement between ownership and the upper tier of the salaried class, with "partnership income" becoming increasingly significant in the composition of the remuneration of this upper echelon of the salaried class who, because the "discipline" of the wage relation has been swept to one side for its members, now have income levels that accelerate much more quickly than those who are paid through wages. The available data on income differences bears out this observation, with those making over $\$ 200,000$ a year deriving a greatly increased proportion of their income from capital gains, and the US now reaching levels of income inequality last seen during the "Gilded Age" of the 1920s and 30s (see Figure 1): 


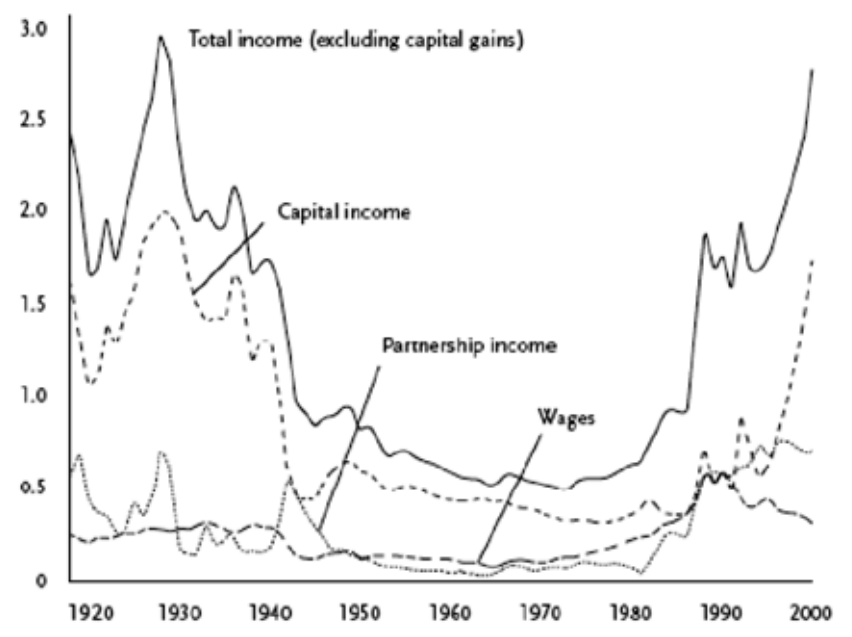

Figure 1: The top $0.01 \%$ income share in US total household income (excluding capital gains) and three components, 1918-2000 (Source: Duménil and Lévy, "Neoliberal Income Trends: Wealth, Class and Ownership in the USA," New Left Review, 30 (new series, 2004), figure 2, 109.)

The new American plutocracy is now visible even in smaller towns in the US, especially those just outside the bigger cities in the Sunbelt (Marietta outside Atlanta, Cary near Raleigh, Reston outside Washington DC, and so on), which find themselves dealing with the challenges of "McMansion" construction, when older properties are torn down to make way for fake mansions with huge foyers, living and dining rooms festooned with chandeliers, garages for four or five sports utility vehicles, a bathroom for every bedroom, a required swimming pool and jacuzzi, and manicured lawns with chemically-treated grass exuding a preternaturally green color ("a greener green than real grass"). These residences are often maintained by teams of low-paid workers, usually immigrants from Central and South America, who do everything from house cleaning to swimming pool maintenance, to providing child care and the inevitable lawn service. ${ }^{9}$ What has enabled this new Gilded Age to come into being, where a few benefit from riches that the overwhelming majority can only dream about?

The brief answer has to be that the new Gilded Age results from a combination of convictions now enshrined in American culture, in conjunction with the economic requirements of the neoliberal regime of accumulation. This "strategic coupling" of culture and economics has resulted in a new kind of politics, a "post-political politics," in which citizens are not really represented, but managed in the interest of a ruthlessly pro-business political agenda. I take this "post-political politics" to be the core of the insight made available by Deleuze in his account of the society of control. Most of the narrative and analysis provided below focuses on the United States, but the "managed citizen" of the US has his or her counterparts in nearly every one of the advanced industrial countries, and so it behooves us to provide a characterization of this quintessential citizen of the society of control. 


\section{THE MANAGED CITIZEN}

Thanks mainly to the means made available by the most recent mass media technologies and the Internet, American, Antipodean, and most western European politics today are representational only in name. If we believe that the core principles of the American system of political representation are provided by the Constitution, then a brief but telling snapshot of what Americans believe regarding their constitutional freedoms is provided by the nonpartisan annual State of the First Amendment survey, conducted since 1997 by the University of Connecticut. ${ }^{10}$ The 2005 survey revealed that $23 \%$ of Americans said "the First Amendment goes too far in the rights it guarantees," compared to 49\% in 2002 (the first survey done after 9-11) and down from 30\% in 2004. The 2003 survey showed that $46 \%$ of those polled believed that the press had too much freedom, and almost one-third of those surveyed in 2003 believed that anti-war protests should be forbidden when America was fighting a war. About $50 \%$ of those surveyed in 2003 said the American press had been too aggressive in asking government representatives for information about the war on terrorism. The 2002 survey showed that more than $40 \%$ wanted to curb the academic freedom of professors and prohibit criticism of US military policy. Around 50\% of those polled in 2002 said the government should be permitted to monitor religious groups in the interest of national security, even at the cost of violating the Constitution's provisions regarding religious freedom. More than $40 \%$ in the 2002 survey said the government should be given greater power to monitor Muslims living in the United States more than other religious groups. So much for the "American love of freedom" touted by George W Bush and his handlers! But what such survey numbers visibly indicate is the very high level of insecurity (with or without an associated threshold of low information) evinced by the respondents involved. The question of the causes that underlie this condition of the American citizenry has to be posed.

Of course, data of the kind provided above are merely symptomatic, and a more complete account of the system that allows such responses as the ones conveyed in these surveys to be "normalised" has to be forthcoming before a clearer sense of the political subjectivities displayed in these survey responses can be gleaned. How can a country that has an apparently inviolable belief in its status as a free and democratic country, a "shining city on the hill" which also happens to be the wealthiest nation in the world, nonetheless have so much social and economic inequality, a patently racialised system of incarceration and the imposition of the death penalty, with over $20 \%$ of its population lacking health insurance (while it spends vast sums of money on its military), as well as having a much poorer record of environmental protection than all other industrialized countries, while also being burdened by a system of institutionalized and legalized political corruption that would scarcely be credible if an attempt were made to introduce it to another advanced industrial nation ${ }^{11}$ What is the nature of the typical modes of political subjectivity that allow such a "post-political" polity to function in the way that it does? Here, at least a sketch of the model responsible for the production of these political subjectivities is needed.

In its ideal and most general form the notion of a representational democracy requires "an informed and involved" citizenry to choose in "free and fair" elections representatives who will then convene with other similarly elected representatives to determine what the laws of that country should be. Hence, it is a truism that the degree to which citizens are not able to 
participate in this system in the prescribed way will indicate that this system is not truly capable of undertaking the functions required by this "ideal type" of representational democracy. How near is the Western model of government to this "ideal type" of representational democracy?

There is nowadays a widespread acknowledgement, irrespective of political affiliation, that the resources for political mobilisation afforded by the latest mass media technologies and the Internet have drastically transformed the nature and forms of political involvement - at least in comparison with the alternatives associated with previously regnant media forms and the strategic opportunities they provided for a putative electorate. The "informed and involved" citizen of the previous paradigm of representational democracy has effectively given way to a new kind of citizen, sometimes referred to as "the managed citizen," "the citizen of governmentality," and so on. ${ }^{12}$

Citizenship in the US today is basically "thin, shadowy, and privatized," to use the description provided by Philip N Howard in his absorbing study of the ways in which objects for political consumption are produced through the application of today's hypermedia technologies. Howard's study draws attention to a fact that has been overlooked in many discussions of citizenship - that historically the US has had many kinds of citizens, each with different "informational needs," and that hypermedia technologies have if anything added to this differentiation. ${ }^{13}$ These new technologies "remove the burden of being informed while expressing public opinion" by privileging voices expressive of outrage at the expense of those that are informed (185). Such voices are invariably required to provide preset responses to political options that have been simplified in advance (for example, more than three years after the US invasion of Iraq, the US media still provides very little scope for those who want to say that Saddam Hussein's regime was without qualification morally unacceptable while also holding to the view that the American invasion of Iraq was a flagrant breach of international law, and that Tony Blair and George W Bush should therefore be charged in an international tribunal for war crimes).

The quintessential manifestation of "thin citizenship" is the computer-generated signature campaign, which requires only a few strokes of the keyboard to make someone feel they are involved in a political movement. Government in such a setting then becomes primarily a matter of being seen to redress grievances, and thus of providing a few "sound bite" positions that can easily be assimilated by "low information" subjects who have relatively crude benchmarks for feeling that the grievances in question are being addressed by officials. A prime-time television appearance by George W Bush in a Potemkin village setting in New Orleans (with special floodlighting of the cathedral background while most of New Orleans was still without electricity, etc.) and a couple of other presidential "appearances" quickly reduced the numbers of those who said in opinion polls that the government was not doing enough to expedite relief after Hurricane Katrina, and helped foster the completely erroneous impression that the (legitimate) grievances of those needing help in New Orleans were being addressed by the Bush administration, when in fact they were not.The floodlights did not shine on the mountains of debris a short distance from where Bush made his reassuring noises in front of the television cameras. The aim of such media orchestrations is less to "convince" those with firmly settled convictions, who are apt to regard themselves as "activists," and 
much more to draw on those less committed factions whose opinion-poll responses can tilt the balance this or that way ("the marginal voter"). The target in these new-media political campaigns tends therefore to be those who are less informed and somewhat wavering in their attitudes - those who, as with their choice of beverage, may in all likelihood want any political option served up to them to be "lite" (and nothing but "lite"). "Political choice" in this kind of media-fuelled "representational democracy" has metamorphosed into the ability to register one's opinions and little else (the individuals with the real choices in such a system are the ones with money-bags heavy enough to induce politicians to do their bidding). The difference between a "politics lite" or "thin democracy" (to use Perry Anderson's phrase), favoring "hot button" single issues and little else, and its real alternative, is stated thus by Philip Howard:

[The hypermedia campaigns] allow citizens to manage their distance from political issues. Candidates must remain ideologically competitive, and they use hypermedia to present different and sometimes conflicting ideological packages to different communities or supporters. The thin polity may have an immense total supply of information that is only sparingly shared among citizens. Information is unevenly distributed among communities, except for citizens with good search skills or those who can hire consultants with good information management skills. Conversely, a thick public sphere would have consistent, rich sources of political information in which all citizens can be immersed. ${ }^{14}$

It would be foolish however to think that the way to restore a "thicker" practice of citizenship is by going back to a Golden Age (which in any event never did exist), in which more people read serious newspapers, took the trouble to be informed about politics, and were more concerned about a candidate's position on the issues of the day than they were about his or her smile, hair color, jawline, lack of height, the rock stars or sports personalities supporting the candidate, etc., etc. Howard makes the point that what did happen in previous times was not anything that accorded with this mythical Golden Age. Rather, what existed then in the US was a system that enabled patronage networks to be lined up behind party positions that were more or less loosely demarcated by ideology, so that to vote "left" generally meant being mildly in favor of worker's rights, welfare transfers, increased spending on education, taxes on corporate profits, etc., and to vote "right" meant voting for lower taxes, reduction of the social safety net, the implementation of pro-business policies, etc. The merits of these patronage networks should not be exaggerated, since they were primarily machines for getting voters to the polls, and had little or sometimes nothing to do with bringing about radical social change. But they did serve the minimal purpose of giving voters effective clues about party alignments on social and economic issues. These patronage networks have now dissolved, as both American parties have become unrelentingly pro-business, hostile to wealth redistribution of even the most restrained kind, in favor of wholesale marketization, reflexively pro-military, and so forth, and can only separate themselves from each other by the populist stances they take on such "value issues" as gun control, gay marriage, the "right to die," abortion, the death penalty, hanging the Ten Commandments in courthouses, prayer in schools, teenage chastity pledges, teaching evolution in schools, schooling for the children of undocumented immigrants, and so on. Both parties are now appendages of the 
military-industrial-entertainment-Wall Street complex, and make no pretense whatsoever of being otherwise. The outcome in the US is a diminished public sphere, with "thin citizenship," culminating in what Tom Mertes has rightly called a "Republican proletariat." 15

This public sphere is further eviscerated by another practice that defines "thin citizenship" - in this case the use made by political organizations of our "data shadow" to shape and predict the preferences of voters. This "shadow" is the "data trail" left behind by citizens as they negotiate life in an electronic society - credit card purchases, magazine subscriptions, polling information, organization memberships, voter registration data, etc. - that can be used by political organizations to "deduce" the different kinds of "political personality" that can then be appealed to through the hypermedia in specifically tailored ways (such as election advertisements with an anti-gun control pitch in districts with a high proportion of licensed hunters, etc.). To quote Howard again:

What is meaningfully represented in contemporary political institutions is not you but your data shadow, the political personality deduced from data about you. Sometimes your opinion diverges from what statistically derived models say your opinion is, and some of us know how to manage our data shadows while others do not. Some of us know what our data shadow looks like, while others do not. However, the data that constitutes [sic] our political personalities, including explicit citizenship acts and the implicit political meanings of consumer behavior, are bought and sold in the market. In this sense, hypermedia campaigns have "privatized citizenship." 16

The informational needs of citizens have thus become commoditized by private businesses which sell the resultant commodities to political organizations for their campaigns. This information is then packaged into a media format that can be "narrowcast" to personalised voter niches (using such labels as "security mom," "town and gown," "pool and patio," "Nascar dad," "New Age and granola," etc., to specify these niches), and the result is an informational political culture that more and more resembles the kind of "infotainment" peddled on cable television. As a consequence, says Howard,

the incentive to participate is not the public service but relief from private wrongs, as framed by hypermedia campaigns. Political hypermedia are designed to move democratic conduct from the public sphere of rallies, town hall meetings, newspaper editorials, and coffee shop debates to the private sphere of screens, key strokes, and highly personalized news services. For campaign managers and policy makers, commercial data about voter preferences make it easier to evaluate and push both public and individual sentiments .... [P]olitical hypermedia are deliberately designed to privatize in multiple senses of the word: to move the logistics of citizenship from the public to the private sector, into the private world of home and work space, where individuals act more out of private discontent on select issues than out of public duty for collective welfare. ${ }^{17}$

As a result, citizens are increasingly likely to be mobilized by a "backlash" populism that trades on the resentments of voters, whether real or (as is more likely to be the case) trumped up by a demagogic hypermedia campaign. Hypermedia campaigns can also be used to destroy 
the credibility of political opponents, as shown by the Willie Horton episode that helped get Bush Senior elected, or the "Swift Boat" Veterans media campaign in the 2004 presidential election which deflected attention from Bush Junior's patchy record in the National Guard during the Vietnam War.

"Thin citizenship" is amplified by the growing contribution cybertechnology makes to the society of the spectacle, which now so thoroughly permeates American politics that political campaigns are effectively reduced to a set formula, namely, "spin plus spectacle." Thus George W Bush was seen landing on an aircraft carrier in his flight suit; an uncomfortable-looking Michael Dukakis was televised riding in the turret of a massive tank in the 1988 presidential campaign; the toppling of the statue of Saddam Hussein (with the Stars and Stripes attached to its head), when the first phase of the American invasion was completed, turned out to be a well-staged media event and not a spontaneous act on the part of Iraqi citizens. Tony Blair had his "I'm the uniter of the nation" moment in front of the television cameras when Princess Diana died, and politicians flock to disaster sites like vultures, knowing the cameras will be there to show them in their "leadership roles." Even the refusal of the US Department of Defense to allow cameras to film the arrival of the caskets of US military personnel killed in Iraq testifies to the power of the society of the spectacle: in this case, of course, the fear of the government is that the true nature of the price being paid by poorer Americans who join the military to have what they think will be a better life will be shown all too clearly. ${ }^{18}$

In the era of managed citizenship, as described above, political advantage is perceived or projected to lie in "the center" (Clintonite "triangulation," Blair's "Third Way," and so on), and this perception has two consequences: parties gravitate towards the right while giving the illusion that it is their opponents who have in fact abandoned the center, and political élites become increasingly disconnected from their voters. Thus the US has two right-wing parties, a no-holds-barred right-wing party, and an indistinctly right-wing party ("I support the center, but I'm leaning, leaning to the center right" would be the appropriate refrain for most Democratic politicians in the US today); and the same is true in Britain of both Blair's "New" Labour and the Conservative Party. ${ }^{19}$ If there is a serious third party in an election in the US or UK (these countries being the prime exemplars of the Anglo-Saxon model of neoliberal capitalism, and thus of the control society), it has invariably to struggle to fit itself into this schema which allows the two main parties to move to the right while conveying the impression that the "third" or "alternative" party is by its very nature too "extremist" to belong to the fictitious center defined by the two established parties. The Rainbow Coalition's efforts in the 1988 US presidential election and Ralph Nader's campaign in the 2000 presidential election were both portrayed by "mainstream" Democrats and Republicans alike as too "extremist" to deserve votes. Similarly, any attempt in British politics by the third-party Liberal Democrats to make a move away from this fictitious "center" in a more progressive direction is immediately stigmatised by both Labour and Conservative politicians as an unacceptable "lurch to the left."

Another consequence of this shift to a system of managed citizenship has been to move the emphasis away from parties and ideological platforms and place it instead on the "personalities" (already shaped by the "behavior technologies" of the hypermedia system) of candidates - who must then have the money to run a protracted media campaign if they are to get anywhere. But candidates per se are never as durable as traditional parties and the 
ideologies they embody and, with the deemphasizing of the latter, electorates have weak and tenuous links to the parties they notionally vote for: if a "more attractive" candidate shows up for the opposing party in the next election, then one simply changes one's allegiance and "splits the ticket" at the next election. Hence, a significant number of working-class Democrats voted for George W Bush in 2004 , enticed by his “moral stance” on gay marriage, just as they voted in overwhelming numbers for Ronald Reagan in 1980 and 1984 on the basis of his airy proclamations to the effect that it was “morning again in America” (Reagan's pronouncements were even then characterised by pundits and "opinion shapers" as part of the "feel good" factor in politics that can win elections for those who in truth are singularly uninformed and not very intelligent candidates, but who can prevail electorally if they make enough voters "feel good").

In an era where citizenship is now managed, the question of political transformation poses itself even more urgently. A managed citizenry, beholden to the seemingly endless succession of spectacles that are now the focal point of contemporary political campaigning in such control societies, will in all probability not be in a position to initiate a radical political shift in favour of those who are impoverished and socially marginalized. The government in such a control society has sufficient resources to neutralize opposition to its ruling élites by changing its strategies of citizen management and by putting on new spectacles. The high proportion of respondents in polls taken around the start of the American occupation of Iraq who believed that Saddam Hussein was responsible for the World Trade Center bombings is a telling reminder of the American state's power to dragoon its people into compliance through media manipulation and fear-instilling propaganda.

This indicates that the impetus for comprehensive and radical social change will have to come from those parts of the world where there is no such system of managed citizenship, nor the resources for launching a society of the spectacle. This points to the countries of the South, who have a considerably greater incentive to overthrow an economic system that confers systemic advantages on the wealthy industrialized countries to the disadvantage of the South, even if at the same time not all these advantages are reflected in the incomes of the poorest citizens of the countries of the North (and the US in particular). But the managed citizenry which increasingly populates the wealthy countries of the North and West is of course not really interested in bringing about significant changes that will help the countries of the South and East, especially if these changes involve substantial wealth transfers from the North to the South. Moreover, the attempts by the richer nations to promote a "low-intensity democracy" in the poorer countries (which will not really change much in a poor country, but which will do enough to ensure the modicum of stability required to let multinational corporations get on with their business) have their exact complement in their governments' own efforts to manage their citizens in order to ensure compliancy. ${ }^{20}$

In both zones, North/West and South/East, what is fundamentally being sought is the wholesale quiescence of citizens. Is this the pass that things have come to in the age of control societies: a citizenry managed through the cybernetic technologies in the North/West, while the countries of the South/East make do with a promised patina of democratic and human rights while having to toe the line set down by the IMF and World Bank, or else face ostracism from the international economic order? ${ }^{21}$

22 Surin - Society of Control - Junctures, 8, Jun 2007 
1 Gilles Deleuze, "Postscript on Control Societies," in his Negotiations, 1972-1990, trans. Martin Joughin (New York: Columbia University Press, 1995), 177-82. Originally published as Pourparlers (Paris: Minuit, 1990). I summarize Deleuze's "Postscript" in my "Control Society and State Theory," in The Deleuze Dictionary, ed. Adrian Parr (New York: Columbia University Press, 2006), 54-7, from which several formulations are taken for the paragraphs below.

2 Bruno Théret, "Theoretical Problems in International Comparisons: Toward a Reciprocal Improvement of Societal Approach and Regulation Theory by Methodic Structuralism," in Association Recherche \& Régulation, available at http://web.upmfgrenoble.fr/regulation/Journees_d_etude/Journee_1998/ theret.htm, last accessed on 22 January 2007. The Regulationist approach allows for a "contestation" between societal groupings, but does not view this "contestation" in terms of a structural opposition that is class-based. The approach taken in this paper views this contestation to be primarily, though not exclusively, class-based. What is convincing about the Regulationist approach is its insistence that each of these spheres (the economic, the political, and the domestic) has its own internal operational logic, though each sphere also interacts with its counterparts. I argue more fully for this position in my Freedom Not Yet: Liberation and the Next World Order (Durham, NC: Duke University Press, in press).

3 On this see Robert Brenner, "Structure vs Conjuncture: The 2006 Elections And The Rightward Shift," New Left Review, 43 (new series, 2007), 33-59.

4 Some would object that few Americans, if any, would approve of the business practices of Enron once they became aware of them. The obvious rejoinder to this objection is that we cannot be sure how many Americans would have objected to Enron's business practices if it had not gone out of business in a way that begged for its senior managers to end up in front of a judge. After all, relatively few Americans now seem to object to the business practices of Halliburton, involving as it does (officially documented) over-charging, various forms of governmental favoritism, and so forth.

5 For Gramm's election pitch, see David Plotz, "Phil Gramm," Slate Website, available on the Web at http://www.slate.com/id/114972/\#ContinueArticle, last accessed on 22 January 2007. Gramm himself received $\$ 260,000$ in campaign contributions from Enron, in return for which he expedited legislation which exempted firms like Enron from energy trading regulation. On this, see Robert Scheer, "Put the Politicians in the Enron Docket," Truthdig.com, available on the Web at http://www.truthout. org/docs_2006/0201060.shtml, last accessed on 2 February 2007. Gramm's wife Wendy was also given a position on the Enron board of directors. Gramm by all accounts was thus an accomplished "rider of the wagon."

6 As Perry Anderson rightly points out, since the poorest Americans do not vote, what ensues in elections is functionally equivalent to a property franchise. See Anderson, "US Elections: Testing Formula Two," New Left Review, 8 (new series, 2001), 8. See also Anderson, A Zone of Engagement (London: Verso, 1992), 357, where he says:

Democracy is indeed now more widespread than ever before. But it is also thinner - as if the more universally available it becomes, the less active meaning it retains. The United States itself is the paradigmatic example: a society in which less than half the citizens vote, ninety per cent of Congressmen are re-elected, and the price of office is cash by the million.

Anderson could have added that the reward of gaining office is also "cash by the million."

7 For the details needed to underpin this sketch of the American mode of societal regulation, I have consulted the following: Anatol Lieven, America Right or Wrong: An Anatomy of American Nationalism (Oxford: Oxford University Press, 2004); Stefan Halper and Jonathan Clarke, America Alone: The Neo-Conservatives and the Global Order (Cambridge: Cambridge University Press, 2004); Jacob Hacker and Paul Pierson, Off Center: The Republican Revolution and the Erosion of American Democracy (New Haven: Yale University Press, 2004); and Godfrey Hodgson, More Equal than Others 
(Princeton, NJ: Princeton University Press, 2004). I have deliberately chosen to cite works by those likely to be identified as "thoughtful" liberals (though both Halper and Clarke served in the Reagan administration), as opposed to Marxists - that is, liberals who give clear voice to the various "erosions" associated with the current Bush administration. At the same time there is a hand-wringing quality to these works, which manifests itself in their genuflections to "America's pluralistic traditions," "the centrality of the Constitution," "the vital center ground," and so forth. Clearly the US Supreme Court putsch that brought George W Bush to the White House has been a source of anguish for well-meaning liberals and/or mild conservatives, but an adequate understanding of the impulses and methods that brought people like Cheney, Rumsfeld, and Wolfowitz to positions of supreme power is not going to be achieved by pious references to the Constitution or to "pluralism" or to "the center:" We are dealing with a political party that has abandoned all notions of the center, that will pay lip-service to the Constitution when this is convenient but not beyond that, and which, in the not-too-subtle words of Bush's "political strategist" Karl Rove, seems to think that those who decry the loss of American "pluralism" are really on the side of al-Qaida. But the declarations or intimations of a sense of loss in these books should not be dismissed: what they convey in their sense of loss and foreboding, albeit at the same time quite inadvertently, is precisely what the American mode of societal regulation has truly managed to accomplish.

8 See Gérard Duménil and Dominique Lévy, “Neoliberal Income Trends: Wealth, Class and Ownership in the USA," New Left Review, 30 (new series, 2004), 105-33.

9 As of 20 January 2006, the mayor of Atlanta, Shirley Franklin, placed a temporary ban on the construction of "McMansions" in her city.

10 For this and the subsequently-detailed information regarding the First Amendment surveys provided in this chapter, see the Center for Survey Research \& Analysis at the University of Connecticut Website at http://csra.stamford.uconn.edu/research.html, last accessed on 28 January 2006.

11 A country so wealthy and powerful is in a position to influence the course of events just about anywhere in the world, and this in turn places a premium on the understanding its citizens have of the rest of the world - though here the indications are not reassuring. It is difficult to ascertain the extent to which the lack of a passport is indicative of a reduced interest in the world beyond one's country, but it is frequently noted that the citizens of other developed countries are much more likely to own passports than their American counterparts. It is estimated that only $21 \%$ of Americans currently own passports (in itself a record number for the US, and of course a great many of these are naturalized citizens who need an American passport to travel to their country of origin). For a discussion of this ostensible American disinterest in the rest of the world, see Alkman Granitsas, "Americans are Tuning Out the World," Yale Center for the Study of Globalization Website, available on the Web at http://yaleglobal.yale.edu/display.article?id=6553, last accessed on 28 January 2007.

12 For the "managed citizen," see Philip N Howard, New Media Campaigns and the Managed Citizen (Cambridge: Cambridge University Press, 2006), and for the thesis that modern (i.e. Western) freedom does not counter government but is in fact one of the latter's least acknowledged inventions, see the Foucault-inspired argument in Nikolas Rose, Powers of Freedom: Reframing Political Thought (Cambridge: Cambridge University Press, 1999), and his "Governing Cities, Governing Citizens" in Democracy, Citizenship and the Global City, ed. Engin F Isin (London: Routledge, 2000), 95-109.

13 See Howard, New Media Campaigns, 184.

14 See Howard, 186.

15 The book which more than any other charts this American capitulation to a right-wing populism is Thomas Frank's best-selling What's the Matter with Kansas?: How Conservatives Won the Heart of America (New York: Metropolitan Books, 2004). Franks, however, does look back to a Golden Age in which the Democratic Party stood for "real" social and economic change. Tom Mertes rightly takes 
him to task on this, and suggests that the Democrats were never really a party with a deep interest in egalitarianism. For Mertes, see his "A Republican Proletariat," New Left Review, 30 (new series, 2004), 37-47.

16 See Howard, 189.

17 Ibid., 190.

18 A powerful account of the way the society of the spectacle feeds the current US government's militaryeconomic strategies in its endless "war on terror" is to be found in Retort (lain Boal, TJ Clark, Joseph Matthews, Michael Watts), Afflicted Powers: Capital and Spectacle in an Age of War (London: Verso, 2005). But perhaps the most powerful and at the same time cynical manifestations of the spectacle have to do with the heavily media-focused responses of the richer nations to the plight of the African countries. G8 summits regularly make a point of "dealing" with the issue of African poverty, but beyond a few televised gestures of "compassion" very little is done to help African nations. On this, see Tom Nairn, "At the G8," London Review of Books, 27:15 (4 August 2005), 19-20.

19 On the British situation, see the informative article by Ross McKibbin, "The Destruction of the Public Sphere," London Review of Books, 28:1 (5 January 2006), 3 and 6.

20 On the part played by "low-intensity democracy" in US foreign policy, and its impact in Latin America and Asia, see William I Robinson, Promoting Polyarchy: Globalization, US Intervention, and Hegemony (Cambridge: Cambridge University Press, 1996). The United States practices its own kind of "low-intensity democracy," since it is a corollary of managed citizenship that the citizens thus managed show a high degree of political disengagement in the public sphere. This is exactly the conclusion drawn from the empirical studies discussed in Nina Eliasoph, Avoiding Politics: How Americans Produce Apathy in Everyday Life (Cambridge: Cambridge University Press, 1998).

Kenneth Surin is Professor of Literature and Professor of Religion and Critical Theory at Duke University in the USA. Surin's Freedom Not Yet: Liberation and the Next World Order is forthcoming from Duke University Press. 